\title{
Adoption of Improved Soybean Varieties and Differences in Technical Efficiency Between Improved and Local Soybean Varieties in Southern Shan State, Myanmar
}

\author{
Ei Thazin Soe ${ }^{1}$, Yoshifumi Takahashi ${ }^{2} \&$ Mitsuyasu Yabe ${ }^{2}$ \\ ${ }^{1}$ Graduate School of Bioresource and Bioenvironmental Science, Department of Agricultural and Resource \\ Economics, Kyushu University, Fukuoka, Japan \\ ${ }^{2}$ Laboratory of Environmental Economics, Department of Agricultural and Resource Economics, Faculty of \\ Agriculture, Kyushu University, Fukuoka, Japan \\ Correspondence: Mitsuyasu Yabe, Laboratory of Environmental Economics, Department of Agricultural and \\ Resource Economics, Faculty of Agriculture, Kyushu University, Motooka 744, Nishi-ku, Fukuoka 819-0395, \\ Japan. Tel: 81-(0)-92-802-4838. E-mail: yabe@agr.kyushu-u.ac.jp
}

Received: March 5, 2020

Accepted: May 17, 2020

Online Published: July 15, 2020

doi: $10.5539 /$ jas.v12n8p55

URL: https://doi.org/10.5539/jas.v12n8p55

\begin{abstract}
This study determined the factors influencing the adoption of improved soybean varieties and examined the technical efficiencies of improved and local soybean varieties production in Southern Shan State, Myanmar. For this study, data from a sample of 337 respondents were collected by employing a multi-stage random sampling method. Logit model was adopted to determine the factors influencing the adoption of improved soybean varieties. Additionally, a stochastic production frontier was used to examine technical efficiencies of improved and local soybean varieties. Results show that factors that positively and significantly influence the adoption of improved soybean varieties are education, market access, extension access and training access. Examination of technical efficiency reveals that labor, fertilizer, machinery, and use of pesticide and harvester are inputs that significantly contribute to improving production efficiency among the improved variety farmers while seeds, labor, and fertilizer are significant inputs of local soybean production. On average, the estimated yield of the improved soybean varieties is $1.51 \mathrm{t} / \mathrm{ha}$, which is higher than the yield of local soybean varieties grown at 0.88 t/ha. It was also revealed that improved soybean varieties had a relatively higher level of mean technical efficiency $(85.04 \%)$ than local varieties $(70.13 \%)$ and significantly different at $1 \%$ level. The results show that improved soybean production is more efficient than local soybean production. Therefore, government and non-government organizations should improve and provide market access, efficient and effective extension services and training to encourage farmers to adopt improved soybean varieties.
\end{abstract}

Keywords: adoption, logit model, stochastic frontier analysis, soybean, technical efficiency

\section{Introduction}

Myanmar is an agricultural country, and the agriculture sector forms the backbone of its economy. Myanmar's agriculture sector including the livestock sector, contributed to $28.6 \%$ of the total GDP, $25.5 \%$ of the total export earnings, and employed 61.2\% of the labor force in 2015-2016 (MOALI, 2016).

According to the primary objective "enhancing productivity in Agriculture" of the Ministry of Agriculture, Livestock and Irrigation (MOALI), the government of the Union of Myanmar has given high priority to improve the productivity of soybean in recent years, as one of the exportable pulses and as an oil-seed crop to attain self-sufficiency in oil consumption.

Pulses were produced in Myanmar since the imperial period. Soybean, chickpea, butter pea, green gram, black gram, pigeon pea, kidney bean, cowpea, lab lab bean, sultani, and sultapya are the major pulses grown in Myanmar. The major exportable varieties of pulses are black gram, green gram, pigeon pea, soybean, butter bean, cowpea and kidney bean.

Soybean is regarded as a "miracle" or "golden" because of its nutritive and economic value. It contains more than $36 \%$ high-quality protein; $30 \%$ carbohydrates; $20 \%$ of edible vegetable oil; and significant amounts of dietary 
fiber, vitamins, and minerals (Lim, 2012). Soybean is meant for both human consumption and livestock feeding. The current soybean producing area is 149,000 ha countrywide with the production accounting for 226,000 MT and an average yield of 1.52 MT/ha (MOALI, 2016). Soybeans are grown in the Southern Shan State more than in any other part of the country, and majority of soybean ( $52 \%$ of the country's production) is produced in the highlands of the Shan State: 22\% is produced in Southern Shan, 21\% in Northern Shan, and 9\% in Eastern Shan.

In the 1970s, there was low yield and low productivity of soybean because of the production of a local variety that was thermos-and photo-sensitive. Thus, the government introduced the exotic varieties since 1991 (Win \& Chumjai, 2009). Presently, there are about 10 soybean varieties that are grown in Myanmar. In 2012, Yezin 6, Yezin 15, Yezin 14, Yezin 12, Yezin 2 and SB 60werereleased as improved varieties by the Department of Agricultural Research at Yezin in Myanmar. Among them, Yezin 14, Yezin 15 and SB 60 varieties were more adaptable for the Southern Shan State and moderately resistant to soybean rust and Downey mildew disease. Additionally, these varieties could be grown everywhere in the rainy season. The yield of improved soybean varieties is $30-35 \%$ higher than the local varieties, and it has shorter maturing time than local varieties (MOALI, 2016). The price of improved varieties is $\$ 1$ per kilogram while the price of local varieties is $\$ 0.69$ per kilogram. Despite high-yield that has been produced from improved soybean varieties, knowledge and technology transfer is still weak and productivity still stagnant. This can be attributed to the fact that soybean producers in the study area are mainly dominated by small-scale farmers who are using traditional tools and equipment. Other factors responsible for this stagnancy are conventional farming and post-harvested treatment techniques; inappropriate use of inputs such as seeds, fertilizer, and pesticides (Win \& Chumjai, 2009; Taphe, Agbo, \& Ebe, 2015); poor infrastructures; and poor market access. According to the data, only about $5 \%$ of the farmers have adopted improved soybean varieties in the Southern Shan State.

There is a daily increase in the local soybean demand in Myanmar because of its natural value and economical feature. To fulfill the domestic requirement and to encourage the greater adoption of improved soybean varieties, we need to understand the farmers' preference and their desirable characteristics for soybean by develop the infrastructure and the technology to increase productivity.

Some authors have studied the effects of the adoption of improved varieties on efficiency. (Oyekale \& Idjesa, 2009) evaluated the adoption of improved maize seeds and efficiency levels of farmers in Nigeria. The results showed that education, farming experience and the use of fertilizer significantly influenced adoption. Hybrid maize seeds were found to reduce inefficiency along with the other factors such as age, experience, and fertilization. Islam, Sumelius, and Bäckman (2012) used stochastic frontier production functions to estimate the technical efficiency of farmers growing traditional varieties (TV) and farmers growing the high-yielding variety (HYV) of rice, concerning their adoption of HYV rice growing in Bangladesh. The results revealed that HYV rice production was associated with lower technical efficiency and a higher yield variability compared to TV. Revenue earned from HYV rice was higher than the revenue earned from traditional varieties. The factors like farmers' age and experience, level of technical efficiency, off-farm income, access to microfinance and perception of yield significantly and positively influenced the adoption of HYV rice.

Asante et al. (2014) also examined the adoption of improved rice varieties and its impact on technical efficiency. The analysis suggested that the adoption rate was $68 \%$ among the sampled rice farmers and average technical efficiency was $69.1 \%$. Adoption of improved rice varieties was found to have a positive and significant impact on technical efficiency. It was also suggested that access to improved varieties is an essential factor in promoting interventions intended to improve technical efficiency. Yusuf and Nwachukwu (2015) estimated the technical efficiency of improved cowpea variety's production in Nigeria. The three variables - seed, herbicides, and insecticide were the significant inputs that influenced the yield. The mean technical efficiency of $76 \%$ indicated that farmers were operating below the frontier level. It was also showed that the variables of age and farm experience were the significant socio-economic variables of determinants of technical efficiency. Fatima and Khan (2015) studied the influence of modern and traditional wheat varieties on technical efficiency and production of the wheat crop in Pakistan. The result of technical efficiency analysis showed that the farmers who adopted traditional wheat varieties were comparatively less efficient than the farmers who cultivated modern wheat varieties. The traditional wheat varieties had a negative impact on the wheat yield.

Some empirical studies on the adoption of improved soybean varieties (Chianu et al., 2006; Ojiako, Manyong, \& Ikpi, 2007; Kapalasa, 2014; Diro \& Mulugeta, 2015) focused only on adoption decision and did not focused on the relationship between adoption and technical efficiency. Hence, very little is known about the differences in technical efficiency between improved and local soybean varieties. 
Besides, there is no evidence yet about the farmer's attitude towards the adoption of improved soybean varieties in Myanmar. This study can contribute to the literature on improved varieties adoption and efficiency by examining the factors affecting the adoption of improved soybean varieties on technical efficiency. Besides focusing on the socio-economic factors affecting the farmers' perception of improved varieties adoption, this study aims to examine the determinants of technical efficiency and compare the technical efficiencies between improved and local soybean varieties.

This study consists of three objectives. For the first objective, we employed the logit model to investigate the factors that influence the adoption of improved soybean varieties. We adopted the stochastic frontier model for the second and third objectives; to establish the differences in technical efficiency between farmers of improved and local soybean varieties, and establish the determinants of technical efficiency respectively.

\section{Research Methods}

\subsection{Study Area}

This study was conducted between August September 2017 in Pindaya, Lawsawk and Taunggyi Townships of Southern Shan State, Myanmar, by using cross-sectional data. The Southern Shan State is located between latitudes $20^{\circ} 59^{\prime} 30^{\prime \prime} \mathrm{N}$ to longitude $97^{\circ} 31^{\prime} 15^{\prime \prime} \mathrm{N}$. Soybeans are grown in Southern Shan more than in any other parts of the country, and the selected townships are the area where improved soybean varieties and technologies were initially introduced.

\subsection{Data Sampling Technique}

Primary data and relevant information were collected using the structured questionnaire, and the interviews focused on soybean growers. The secondary data were collected from websites, the internet, textbooks, scholarly works, journals and local government and non-government organizations. For this study, data were collected using a multi-stage, random sampling method. In the first stage, three major soybean producing areas-Pindaya, Lawsawk, and Taunggyi of Southern Shan were purposely picked on the basis of their comparative concern in improving the local soybean production. In the second stage, 19 villages were randomly selected from the list of communities in those townships with the aid of the local agriculture department. In the final stage, a total of 337 respondents were randomly selected; 220 were improved soybean farmers, and 117 were local soybean farmers.

\subsection{Data Analysis Methods}

During of the survey of this study, the growers who cultivate improved soybean varieties are collected as adopters, while others who cultivate only traditional/local varieties are collected as non-adopters. To examine the factors affecting the adoption of improved varieties and technical efficiency, the model specifications were treated into two parts. First, the significant factors influencing the adoption of improved varieties were identified using the logit model. In the second part, stochastic frontier models were used to determine the technical efficiency differences between adopters and non-adopters and to examine the determinants of technical efficiency. Computer program software STATA12 and Frontier 4.1 were used to estimate the models.

\subsection{Theoretical Logit Model}

The dependent variables in the adoption model are 1.0 (dummy variables), wherein 1 indicates if a farmer grew an improved soybean variety in the 2016/2017 agricultural year, and 0 if otherwise (Lopes 2010). The logit model is widely used in choosing between two alternatives; in this case, the decision was to either adopt or not adopt improved soybean varieties. Several authors (Idrisa, Ogunbameru, \& Amaza, 2010; Akudugu, Guo, \& Dadzie, 2012; Goswami, Choudhury, \& Saikia, 2012; Myint \& Napasintuwong, 2016) have studied adoption by and diffusion of agricultural innovations. According to the literature review, the probit and logit models have been used extensively in most of the adoption studies to identify the decision made for new agricultural technology adoption. In the present study, logit model was used as an analytical tool to determine the factors affecting the adoption of improved soybean varieties because of its simplicity and mathematical convenience (Greene, 2002).

Here, the dependent variable $A_{i}$ is binary in nature, taking value 1 , if a farmer adopts improved soybean varieties and 0 , if he does not.

Let us assume $P_{i}$ be the probability that a farmer adopts improved soybean varieties and $1-P_{i}$ defines the probability that the farmer does not adopt. According to Gujarati (2004), the general form of the probability that a farmer who adopts improved soybean varieties is given as,

$$
P_{i}=\frac{e^{\beta_{i} X_{i}}}{1+e^{\beta_{i} X_{i}}}
$$


and the probability that a farmer who do not improved soybean varieties is given by,

$$
1-\mathrm{P}_{\mathrm{i}}=\frac{1}{1+\mathrm{e}_{\mathrm{i}}^{\mathrm{X}_{\mathrm{i}}}}
$$

where, $\beta_{\mathrm{i}}$ is vector of unknown coefficients, and $X_{\mathrm{i}}$ is vector of explanatory variables.

From Equations (1) and (2), we got,

$$
\frac{P_{i}}{1-P_{i}}=e^{\beta_{i} X_{i}}
$$

Equation (3) indicates the odds ratio in adoption of improved soybean varieties.

Now by taking natural logarithms to both side, we got,

$$
\mathrm{L}_{\mathrm{i}}=\ln \left(\frac{\mathrm{P}_{\mathrm{i}}}{1-\mathrm{P}_{\mathrm{i}}}\right)=\beta_{\mathrm{i}} \mathrm{X}_{\mathrm{i}}
$$

Equation (4) represents a logit model that shows log of odds ratio in adoption of improved soybean varieties.

Since the coefficients of the independent variables cannot be interpreted directly in the logit or the probit models, we should consider the marginal effects to measure the sensitivity of the probability to the independent variables. According to Gujarati (2004), regression analysis is employed to estimate the marginal effect of an independent variable on the dependent variable. Although in the linear regression model, the estimated parameters can be interpreted as marginal effects, in the non-linear regression model or the binary regression model (e.g., logit and probit models), the estimated parameters cannot be interpreted as marginal effects. Therefore, the marginal effect of an independent variable can be calculated by the derivative of the outcome probability regarding an independent variable (Lopes, 2010).

\subsection{Empirical Logit Model}

The logit model was employed to identify the factors affecting the adoption of improved soybean varieties, by using the household's socioeconomic, demographic, and institutional characteristics. The empirical logit model can be stated as:

$$
A_{i}=\gamma_{0}+\gamma_{1} X_{1 \mathrm{i}}+\gamma_{2} X_{2 i}+\gamma_{3} X_{3 i}+\gamma_{4} X_{4 i}+\gamma_{5} X_{5 i}+\gamma_{6} X_{6 i}+\gamma_{7} X_{7 i}+\gamma_{8} X_{8 i}+\gamma_{9} X_{9 i}+\gamma_{10} X_{10 \mathrm{i}}+e_{i}
$$

where, $A_{i}=$ household's adoption of improved soybean varieties (dummy variable, 1 = adopter, $0=$ otherwise); $\mathrm{X}_{1 \mathrm{i}}=$ gender (dummy variable, $1=$ male, $0=$ female); $\mathrm{X}_{2 \mathrm{i}}=$ age of the farmer (years); $\mathrm{X}_{3 \mathrm{i}}=$ education in schooling years (years); $X_{4 \mathrm{i}}=$ number of family member in agriculture (number); $\mathrm{X}_{5 \mathrm{i}}=$ farm size in number (ha); $\mathrm{X}_{6 \mathrm{i}}=$ farm experience (years); $\mathrm{X}_{7 \mathrm{i}}=$ market access (dummy variable, $1=$ yes, $0=$ otherwise); $\mathrm{X}_{8 \mathrm{i}}=$ credit access (dummy variable, $1=$ yes, $0=$ otherwise); $X_{9 \mathrm{i}}=$ extension access (dummy variable, $1=$ yes, $0=$ otherwise); $\mathrm{X}_{10 \mathrm{i}}=$ training access on improved soybean production (dummy variable, $1=$ yes, $0=$ otherwise); $\gamma=$ parameters to be estimated; and $\mathrm{e}_{\mathrm{i}}=$ error term.

\subsection{Theoretical Stochastic Frontier Production Function}

Technical efficiency means the ability of a firm to produce a possible amount of maximal output using a given set of inputs (output orientation) or to produce an output using the lowest possible amount of inputs (input orientation) (Farrell, 1957; Wakili \& Isa, 2015). Present study is focus only on output oriented technical efficiency analysis- by how much soybean output could be increased by using the given level of inputs. In measuring the efficiency and productivity, two approaches are usually applied by researchers- the stochastic frontier production (SFA) (Aigner, Lovell, \& Schmidt, 1977; Meeusen \& van den Broeck, 1977) and Data Envelopment Analysis (DEA) (Charnes, Cooper, \& Rhodes, 1978). These two main approaches were identified as noteworthy by Coelli, Prasada Rao, O’Donnel, and Batesse (2005). The SFA is preferred for agricultural determinations over DEA, specifically in developing countries because we believe that data are likely to be influenced by measurement errors and factors outside of farmers' control, such as weather conditions, pests, and plant diseases (Avea et al., 2016). Especially, SFA is useful for estimating the production function and technical efficiency effects simultaneously. In our experience, there are no studies that have analyzed differences in technical efficiency between improved and local soybean production in Myanmar. Thus, following Aigner, Lovell, and Schmidt (1977), and Meeusen and van den Broeck (1977), the stochastic frontier model for estimation can be specified as follows:

$$
\mathrm{y}_{\mathrm{i}}=\mathrm{f}\left(\mathrm{x}_{\mathrm{i}}, \beta\right) \exp \left(\mathrm{v}_{\mathrm{i}}\right) \exp \left(-\mathrm{u}_{\mathrm{i}}\right)
$$

where, $y_{i}$ is the production of the $i^{\text {th }}$ farm; $x_{i}$ is a vector of input quantities applied; $\beta$ is a vector of unknown parameters to be estimated; $v_{i}$ denotes random variables associated with the random factors such as measurement errors and those outside of farmers' controls, and $\mathrm{v}_{\mathrm{i}}$ is assumed to be independently and 
identically distributed with zero mean and variance as $\mathrm{v}_{\mathrm{i}} \sim \mathrm{N}\left(0, \sigma_{\mathrm{v}}^{2}\right)$ and independent of $\mathrm{u}_{\mathrm{i}}$; and $\mathrm{u}_{\mathrm{i}}$ is a non-negative random variable associated with the farm-specific characteristics capture the technical inefficiency in production, and $u_{\mathrm{i}}$ is assumed to be independently and identically distributed and truncations (at zero) of the normal distribution with mean $z_{i} \delta$ and variance $\sigma_{u}^{2}$. According to Battese and Coelli (1995), the technical inefficiency effects of $u_{i}$ in Equation (6) can be identified as:

$$
\mathrm{u}_{\mathrm{i}}=\mathrm{z}_{\mathrm{i}} \delta+\mathrm{w}_{\mathrm{i}}
$$

where, $\delta$ is a vector of parameters unknown to be estimated, $w_{i}$ denotes random variables, which are assumed to be the truncations of the normal distribution with zero mean and variance $\sigma_{u}^{2}$ such that the point of truncation is $z_{i} \delta$, and $z_{i}$ denotes the vector of independent variables associated with technical inefficiency, provided that the inefficiency effects are stochastic. The farm-specific stochastic production frontier that represents the maximum possible output using the given level of input $\left(\mathrm{y}_{\mathrm{i}}^{*}\right)$ can be stated as;

$$
y_{i}^{*}=f\left(x_{i}, \beta\right) \exp \left(v_{i}\right)
$$

$y_{i}^{*}$ is the maximum estimated output and Equation (6) can be rewritten using Equation (8) as:

$$
\mathrm{y}_{\mathrm{i}}=\mathrm{y}_{\mathrm{i}}^{*} \exp \left(-\mathrm{u}_{\mathrm{i}}\right)
$$

Subsequently, technical efficiency of the $i^{\text {th }}$ sample farm can be written as,

$$
\mathrm{TE}_{\mathrm{i}}=\frac{\mathrm{y}_{\mathrm{i}}}{\mathrm{y}_{\mathrm{i}}^{*}}=\frac{\mathrm{y}_{\mathrm{i}}^{*} \exp \left(-\mathrm{u}_{\mathrm{i}}\right)}{\mathrm{f}\left(\mathrm{x}_{\mathrm{i}}, \beta\right) \exp \left(\mathrm{v}_{\mathrm{i}}\right)}=\frac{\mathrm{f}\left(\mathrm{x}_{\mathrm{i}}, \beta\right) \exp \left(\mathrm{v}_{\mathrm{i}}\right) \exp \left(-\mathrm{u}_{\mathrm{i}}\right)}{\mathrm{f}\left(\mathrm{x}_{\mathrm{i}}, \beta\right) \exp \left(\mathrm{v}_{\mathrm{i}}\right)}=\exp \left(-\mathrm{u}_{\mathrm{i}}\right)
$$

If $y_{i}$ is equal to $y_{i}^{*}$ then $\mathrm{TE}_{\mathrm{i}}=1$. It suggests $100 \%$ efficiency. The difference between the observed output $\mathrm{y}_{\mathrm{i}}^{*}$ and frontier output $y_{i}^{*}$ is fixed in $u_{i}$ (Dey et al., 2000). If $u_{i}=0$, then it implies that production is on the stochastic frontier and the farm obtains its maximum possible output with the given level of input and technically efficient. If $\mathrm{u}_{\mathrm{i}}>0$, then the production lies below the frontier and indicates that the farm's technical inefficiency.

Equations (6) and (7), the maximum likelihood estimate and the Equation (10), the farm-specific TE are estimated by using the FRONTIER 4.1 package (Coelli, 1996). The variance parameters $\sigma_{\mathrm{u}}^{2}$ and $\sigma_{\mathrm{v}}^{2}$ can be parameterized in terms of:

$$
\begin{gathered}
\sigma^{2}=\sigma_{\mathrm{u}}^{2}+\sigma_{\mathrm{v}}^{2} \\
\gamma=\sigma_{\mathrm{u}}^{2} / \sigma_{\mathrm{v}}^{2}
\end{gathered}
$$

The value $\gamma$ ranges from 0 to 1 . It indicates that the effect of technical inefficiency, with the variance in the observed output, can make a significant contribution to the analysis of the production system (Coelli, Prasada Rao, O’Donnel, \& Batesse, 2005; Latt, Hotta, \& Nanseki, 2011; Khai, Yabe, \& Yokogawa, 2008; Fatima \& Khan, 2015; Avea et al., 2016).

Hypothesis testing is performed by employing a generalized likelihood ratio (LR) test, to determine whether inefficiency effects are present in the model. The generalized likelihood ratio (LR) test is given by

$$
\mathrm{LR}=-2 \log \left[\mathrm{L}\left(\mathrm{H}_{0}\right) / \mathrm{L}\left(\mathrm{H}_{1}\right)\right]
$$

where, $\mathrm{L}\left(\mathrm{H}_{0}\right)$ and $\mathrm{L}\left(\mathrm{H}_{1}\right)$ are the values of the log-likelihood function under the specifications of a restricted frontier model (the null hypothesis $\mathrm{H}_{0}$ ) and an unrestricted model (the alternative hypothesis $\mathrm{H}_{1}$ ), respectively. The test statistics has a chi-squared or a mixed chi-squared $\left(\chi_{\mathrm{R}}^{2}\right)$ distribution with degrees of freedom (df) that is equal to the difference between the number of parameters involved in the alternative and null hypothesis. LR test is greater than the critical chi-squared table value if the null hypothesis $\left(\mathrm{H}_{0}\right)$ is assumed to be rejected $\left(\mathrm{LR}>\chi_{\mathrm{R}}^{2}\right)$. In this case, the critical values of the likelihood ratio test are taken from Table 1 of Kodde and Palm (1986).

\subsection{Empirical Stochastic Frontier Production Function}

In literature, there has been a wide range of stochastic frontier production models proposed by Aigner, Lovell, and Schmidt (1977), and Meeusen and van den Broeck (1977). Among them, the most popular functional forms are the Cobb-Douglas and the translog production functions. The Cobb-Douglas production function was used in the present study because the results of the likelihood ratio test showed that the Cobb-Douglas function was an appropriate model for our data. Additionally, it has also been commonly used in the empirical frontier model estimation, with its most attractive feature being its simplicity (Coelli, 1995). The Cobb-Douglas production function was widely applied in some previous studies (Idiong 2007; Salam, Siddique, \& Parvin, 2012; Mwatete et al., 2015).

The empirical Cobb-Douglass stochastic frontier production function of soybean producing farmers is expressed as follows: 


$$
\operatorname{lny}_{\mathrm{i}}=\beta_{0}+\beta_{1} \ln x_{1 \mathrm{i}}+\beta_{2} \ln _{2 \mathrm{i}}+\beta_{3} \ln x_{3 \mathrm{i}}+\beta_{4} \ln \mathrm{x}_{4 \mathrm{i}}+\beta_{5} \mathrm{~d}_{1 \mathrm{i}}+\beta_{6} \mathrm{~d}_{2 \mathrm{i}}+\beta_{7} \mathrm{~d}_{3 \mathrm{i}}+\mathrm{v}_{\mathrm{i}}-\mathrm{u}_{\mathrm{i}}
$$

where, the dependent variable is the logarithm of soybean yield in tons per hectare. There are two categories of explanatory variables. In the first category, we used the following conventional production factors: $\mathrm{x}_{1 \mathrm{i}}=$ seed rate used $(\mathrm{kg} / \mathrm{ha}), \mathrm{x}_{2 \mathrm{i}}=$ human labor used (man-day/ha), $\mathrm{x}_{3 \mathrm{i}}=$ fertilizer used $(\mathrm{kg} / \mathrm{ha})$, and $\mathrm{x}_{4 \mathrm{i}}=$ machinery cost for land preparation (thousand kyats/ha). The second category includes $\mathrm{d}_{1 \mathrm{i}}=$ pesticide used (dummy $1=$ yes, $0=$ no), $\mathrm{d}_{2 \mathrm{i}}=$ rhizobium used (dummy $1=$ yes, $0=$ no), and $\mathrm{d}_{3 \mathrm{i}}=$ harvester used (dummy $1=$ yes, $0=$ no). $\beta$ denotes the unknown parameters to be estimated. $\mathrm{v}_{\mathrm{i}} \mathrm{s}$ are random errors, assumed to be independently and identically distributed as $\mathrm{N}\left(0, \sigma_{\mathrm{v}}^{2}\right)$ and $\mathrm{u}_{\mathrm{i}} \mathrm{s}$ denotes non-negative random variables associated with technical inefficiency effects, and $u_{i}$ is defined by the truncation of the normal distribution (at zero) with mean $z_{i} \delta$ and variance $\sigma_{u}^{2}$.

The technical inefficiency effects $u_{i}$ are defined as:

$$
\mathrm{u}_{\mathrm{i}}=\delta_{0}+\delta_{1} \mathrm{z}_{1 \mathrm{i}}+\delta_{2} \mathrm{z}_{2 \mathrm{i}}+\delta_{3} \mathrm{z}_{3 \mathrm{i}}+\delta_{4} \mathrm{z}_{4 \mathrm{i}}+\delta_{5} \mathrm{z}_{5 \mathrm{i}}+\delta_{6} \mathrm{z}_{6 \mathrm{i}}+\mathrm{w}_{\mathrm{i}}
$$

where, $\delta=$ parameters to be estimated, $\mathrm{z}_{1 \mathrm{i}}=$ farm size (ha), $\mathrm{z}_{2 \mathrm{i}}=$ gender of household head $(1=$ male, $0=$ female), $\mathrm{z}_{3 \mathrm{i}}=$ age of farmers (years), $\mathrm{z}_{4 \mathrm{i}}=$ soybean farming experiences (years), $\mathrm{z}_{5 \mathrm{i}}=\operatorname{access}$ to credit $(1=$ yes, $0=$ no), $\mathrm{z}_{6 \mathrm{i}}=$ extension access $(1=$ yes, $0=$ no $)$, and $\mathrm{w}_{\mathrm{i}}=$ error term.

\section{Results and Discussion}

\subsection{Data and Variables Description}

The descriptive statistics of the sampled households are presented in Table 1. Overall, $65 \%$ of the farmers had adopted improved soybean varieties. This result is presented in Table 4 . The average education level was about 5 years while the number of family members that participated in agriculture was about 3 persons. The growers of improved varieties that got market access accounted for $89 \%$, while $54 \%$ of the local varieties growers got the market access. Although $75 \%$ of the improved varieties growers received credit, only about $62 \%$ of the local varieties growers got credit. Also, $88 \%$ of the improved farmers had contact with extension agents while $56 \%$ of the local farmers had contact with extension agents. About $79 \%$ of the improved growers belonged to training on soybean production while only about $42 \%$ of local variety growers belonged to training on soybean production and "training" means the farmers who got improved training like use of optimal amount of inputs, improved growing methods, post-harvest technology, pest management technology, etc. The average yield of improved soybean varieties is about 1.51 tons per hectare while local varieties had the yield of soybean about 0.88 ton per hectare. Improved soybean varieties growers used the average amount of fertilizer (such as compound, urea, organic fertilizer) about $134 \mathrm{~kg} / \mathrm{ha}$ while local soybean varieties growers used the average amount of fertilizer about $128 \mathrm{~kg} / \mathrm{ha}$. Adopters' average machinery cost for land preparation was about 47 thousand kyats per hectare while non-adopters' average machinery cost was about 53 thousand kyats per hectare. Although $15 \%$ of the improved varieties producers used rhizobium, only about $3 \%$ of the local varieties growers used rhizobium and "rhizobium" is a kind of bio-fertilizer for the plant nutrients to get Nitrogen and increase the yield of soybean. Also, $85 \%$ of the improved growers used harvester while only 66 percent of the local varieties growers used harvester. 
Table 1. Descriptive statistics of variables used in the study

\begin{tabular}{|c|c|c|c|c|c|c|c|}
\hline \multirow[t]{2}{*}{ Variable } & \multirow[t]{2}{*}{ Definition of variables } & \multicolumn{2}{|c|}{$\begin{array}{c}\text { Improved } \\
\text { (Adopters) } \\
(\mathrm{N}=220)\end{array}$} & \multicolumn{2}{|c|}{$\begin{array}{c}\text { Local } \\
\text { (Non-Adopters) } \\
(\mathrm{N}=117)\end{array}$} & \multicolumn{2}{|c|}{ t-statistics } \\
\hline & & Mean & $\mathrm{SD}$ & Mean & S.D. & & \\
\hline Gender & Household head $(1=$ male, $0=$ female $)$ & 0.88 & 0.32 & 0.82 & 0.39 & 1.47 & \\
\hline Age & Age of the farmer (years) & 46.00 & 11.57 & 48.58 & 12.38 & -1.86 & \\
\hline Education & Education in schooling years (years) & 5.27 & 2.75 & 4.46 & 2.14 & 2.86 & $* *$ \\
\hline Family size & Number of family member in agriculture (number) & 2.69 & 1.16 & 3.12 & 1.26 & -3.09 & $* *$ \\
\hline Farm size & Farm size in number (ha) & 0.92 & 0.65 & 0.81 & 0.55 & 1.52 & \\
\hline Experience & Farming experience (years) & 9.87 & 7.50 & 9.27 & 7.46 & 0.70 & \\
\hline Market & Market access $(1=$ less than $11 \mathrm{~km}, 0=$ more than/equal $11 \mathrm{~km})$ & 0.89 & 0.31 & 0.54 & 0.50 & 7.04 & $* * *$ \\
\hline Credit & Credit access $(1=$ yes, $0=$ no $)$ & 0.75 & 0.43 & 0.62 & 0.49 & 2.34 & $* *$ \\
\hline Extension & Extension access $(1=$ yes, $0=$ no $)$ & 0.88 & 0.33 & 0.56 & 0.50 & 6.28 & $* * *$ \\
\hline Training & Training access on improved soybean cultivation $(1=$ yes, $0=$ no $)$ & 0.79 & 0.40 & 0.42 & 0.50 & 7.07 & $* * *$ \\
\hline Yield & Yield of soybean (ton/ha) & 1.51 & 0.51 & 0.88 & 0.30 & 14.09 & $* * *$ \\
\hline Seed & Seed rate used $(\mathrm{kg} / \mathrm{ha})$ & 60.69 & 19.29 & 60.41 & 19.93 & 0.13 & \\
\hline Labor & Human labor used (man-day/ha) & 50.49 & 17.12 & 53.94 & 21.47 & -1.50 & \\
\hline Fertilizer & Fertilizer used $(\mathrm{kg} / \mathrm{ha})$ & 134.30 & 52.95 & 127.84 & 53.48 & 1.06 & \\
\hline Machinery & Machinery cost for land preparation (thousand kyats/ha) $(1 \mathrm{US} \$=1400$ kyats) & 47.15 & 14.25 & 52.94 & 18.32 & -2.98 & $* *$ \\
\hline Pesticide & Pesticide used $(1=$ yes, $0=$ no $)$ & 0.58 & 0.49 & 0.55 & 0.49 & 0.61 & \\
\hline Rhizobium & Rhizobium used $(1=$ yes, $0=$ no $)$ & 0.15 & 0.36 & 0.03 & 0.18 & 3.93 & $* * *$ \\
\hline Harvester & Use of Harvester $(1=$ yes, $0=$ no $)$ & 0.85 & 0.36 & 0.66 & 0.48 & 3.72 & $* * *$ \\
\hline
\end{tabular}

Note. $* *$ is significant at $5 \%$ and $* * *$ significant at $1 \%$.

Source: Own estimates.

\subsection{Factors Influencing the Adoption of Improved Soybean Varieties}

The logit model was employed to predict the factors influencing the adoption of improved soybean varieties. We obtained LR chi2 $(10)=97.53$ and probability of $\chi^{2}$ larger than 0.0000 which was less than 0.01 . We concluded that the estimated model fitted the data well. Table 2 presents the maximum-likelihood estimated results of the parameters of the logit model. The results indicate that education, family size, market access, extension access and training on improved soybean cultivations are the significant factors affecting the adoption of improved soybean varieties. The coefficient on education was significant at the $5 \%$ level and positively related with the adoption of improved soybean varieties, which revealed that the more educated the farmers are, the more likely they are to adopt improved soybean varieties. It was possible that well-educated farmers had the human capital to access the information more rapidly than the others. This result is in line with that of Ologbon, Ikheloa, and Akerele (2012), and Tiongco and Hossain (2015).

The coefficient of family size was significant at the $5 \%$ level and was negatively associated with adoption. This indicates that family size was negatively related with the adoption of improved soybean varieties. Kudi et al. (2011), and Udensi et al. (2011) also found a similar result. Additionally, if the family size is larger; the adoption level can be lower. The coefficient of market access was positively and highly significant at the $1 \%$ significance level. The results showed that the better market access is significantly associated with the adoption of improved soybean varieties. This result is in line with the findings of Gebre (2001). There was a significant relationship between extension access and the adoption of improved soybean varieties at a $5 \%$ significance level. This implied that the farmers who had contact with extension agents were more likely to adopt the improved varieties. The farmers can obtain information from an extension agent and can apply that information through meetings and demonstrations. This finding is in line with the results of Ojiako, Manyong, and Ikpi (2007), and Miah et al. (2015). The coefficient of training on improved soybean cultivation had a positive effect on the adoption of improved varieties at a 5\% significance level. This result was also found in Barry (2016) implying that the more the training on soybean production, the more is the likelihood of a farmer adopting improved soybean varieties. After determining the factors that affect the adoption of improved soybean varieties, it was necessary to understand the results of changing the value of each significant factor affecting the probability of adoption. Table 3 shows the calculated marginal effects' impact on the probability of adoption. The coefficients of marginal effect indicate that if the educational level increases by $100 \%$, then the probability of improved soybean varieties would increase by $2.6 \%$. Again, the coefficient of the market, extension, and training on improved soybean varieties were positively significant. If these variables increase by $100 \%$, then the probability of adoption of 
improved soybean varieties will increase by $35.3 \%, 19.4 \%$, and $22.5 \%$, respectively. However, if the number of family members increases by $100 \%$, then the probability would decrease by $5.4 \%$.

Table 2. Logit model estimates of the factors determining farmer's adoption of improved soybean varieties

\begin{tabular}{|c|c|c|c|c|}
\hline Variables & Coefficient & Standard Error & z-statistic & Probability \\
\hline Gender & 0.285 & 0.389 & 0.73 & 0.465 \\
\hline Age & 0.001 & 0.012 & 0.07 & 0.941 \\
\hline Education & $0.118 * *$ & 0.060 & 1.96 & 0.050 \\
\hline Family size & $-0.248 * *$ & 0.121 & -2.05 & 0.041 \\
\hline Farm size & 0.359 & 0.233 & 1.54 & 0.123 \\
\hline Experience & -0.019 & 0.019 & -1.01 & 0.311 \\
\hline Market & $1.515 * * *$ & 0.323 & 4.70 & 0.000 \\
\hline Credit & -0.098 & 0.310 & -0.31 & 0.753 \\
\hline Extension & $0.841 * *$ & 0.372 & 2.26 & 0.024 \\
\hline Training & $0.997 * *$ & 0.338 & 2.95 & 0.003 \\
\hline Constant & $-1.957 * *$ & 0.895 & -2.19 & 0.029 \\
\hline \multirow[t]{5}{*}{ Logistic regression } & \multicolumn{3}{|c|}{ Number of obs $=337$} & \\
\hline & \multicolumn{2}{|c|}{$\operatorname{LR} \operatorname{chi} 2(10)=97.53$} & & \\
\hline & \multicolumn{2}{|c|}{ Prob $>$ chi $2=0.0000$} & & \\
\hline & \multicolumn{3}{|c|}{ Log pseudo likelihood $=-168.83$} & \\
\hline & \multicolumn{3}{|c|}{ Pseudo R2 = 0.2241} & \\
\hline
\end{tabular}

Note. $* *$ is significant at a $5 \%$ level and $* * *$ is significant at a $1 \%$ level.

Source: Own estimates.

Table 3. Marginal effect of the variables determining farmer's adoption of improved soybean varieties

\begin{tabular}{lllll}
\hline Variables & Marginal Effect & Standard Error & z-statistic & Probability \\
\hline Gender & 0.064 & 0.090 & 0.71 & 0.478 \\
Age & 0.0002 & 0.003 & 0.07 & 0.941 \\
Education & $0.026 * *$ & 0.013 & 1.97 & 0.049 \\
Family size & $-0.054 * *$ & 0.026 & -2.05 & 0.040 \\
Farm size & 0.078 & 0.050 & 1.54 & 0.123 \\
Experience & -0.004 & 0.004 & -1.01 & 0.311 \\
Market & $0.353 * * *$ & 0.073 & 4.79 & 0.000 \\
Credit & -0.021 & 0.066 & -0.32 & 0.751 \\
Extension & $0.194 * *$ & 0.088 & 2.18 & 0.029 \\
Training & $0.225 * *$ & 0.077 & 2.92 & 0.003
\end{tabular}

Note. ${ }^{* *}$ is significant at a $5 \%$ level and $* * *$ is significant at a $1 \%$ level.

Source: Own estimates.

Table 4. Distribution of respondents according to soybean varieties cultivated

\begin{tabular}{lll}
\hline Soybean varieties & Frequency & $\mathbf{\%}$ \\
\hline Improved varieties & 220 & 65.28 \\
Local varieties & 117 & 34.72 \\
\hline Total & 337 & 100 \\
\hline
\end{tabular}

\subsection{Hypotheses Tests Results}

The results of the hypotheses test for model specification and inefficiency effects of improved and local soybean varieties are stated in Table 5. The first null hypothesis $\left(\mathrm{H}_{0}: \gamma=0\right)$ states that there are no technical inefficiency effects in the production function. The first null hypothesis is strongly rejected at the $1 \%$ significance level (LR statistics 30.18 and $\left.47.04>\chi_{(8,0.99)}^{2}=19.38\right)$, which indicated that there is the presence of technical inefficiency effects in the production. This also revealed that the Cobb-Douglas stochastic frontier production model is 
adequate for the representation of the data. The second null hypothesis $\left(\mathrm{H}_{0}: \delta_{0}=\delta_{1}=\delta_{2}=\delta_{3}=\ldots \delta_{6}=0\right)$ means that the effects of managerial variables on efficiency are not present in the model, which is also rejected at the $1 \%$ significance level for both improved and local soybean varieties (LR statistics 16.89 and $31.44>\chi_{(7,0.95)}^{2}=$ 13.40). This implies that the effects of those managerial variables of technical efficiency significantly contribute to the differences between the observed output and frontier output for both varieties.

Table 5. Likelihood ratio tests of null hypotheses for parameters in the stochastic frontier production function and the technical inefficiency factors for improved and local soybean varieties' farmers

\begin{tabular}{|c|c|c|c|c|c|c|}
\hline \multirow[b]{2}{*}{ Null hypothesis } & \multicolumn{3}{|c|}{ Improved Varieties } & \multicolumn{3}{|c|}{ Local Varieties } \\
\hline & LR Statistics & $\begin{array}{l}\chi^{2} \text {-critical value } \\
\text { (d.f., 0.99) }\end{array}$ & Decision & LR Statistics & $\begin{array}{l}\chi^{2} \text {-critical value } \\
\text { (d.f., 0.99) }\end{array}$ & Decision \\
\hline $\mathrm{H}_{0}: \gamma=0$ & $30.18^{* * *}$ & $\chi_{(8,0.99)}^{2}=19.38$ & reject & $47.04 * * *$ & $\chi_{(8,0.99)}^{2}=19.38$ & reject \\
\hline $\mathrm{H}_{0}: \delta_{0}=\delta_{1}=\delta_{2}=\delta_{3}=\ldots \delta_{6}=0$ & $16.89 * *$ & $\chi_{(7,0.95)}^{2}=13.40$ & reject & $31.44 * * *$ & $\chi_{(7,0.95)}^{2}=13.40$ & reject \\
\hline
\end{tabular}

Note. The critical values are obtained from Table 1 of Kodde and Palm (1986) using the $1 \%$ significance level.

Source: Own estimation from field survey, 2016/17.

\subsection{Empirical Results and Technical Efficiency Analysis}

The maximum likelihood estimates (MLE) of the parameters of the Cobb-Douglas stochastic frontier production function and the inefficiency effects of improved and local soybean varieties were simultaneously estimated by using the computer program FRONTIER 4.1 (Coelli, 1996). The results are presented in Table 6. The table presents the estimation of the parameters of the frontier production function and the inefficiency model. The constant term of improved soybean varieties is higher than that of local soybean varieties. This means that if improved soybean varieties are adopted, then they would contribute to a higher basic yield when compared to local soybean varieties. The results also indicate that all the significant variables in the production function of both varieties are positively significant. This finding indicates that as the variable of input increases, the yield of soybean also increases. Among the improved soybean varieties growers, labor, fertilizer, machinery, pesticide, and harvester are found to be positive and highly significant at the $1 \%$ level, which indicates that increasing the level of these variables will likely to increase the level of the yield of improved soybean varieties. For the local soybean varieties growers, seed, fertilizer, and labor are positively significant at the $1 \%$ and $5 \%$ levels. The positive coefficients of these variable inputs indicate that the increases in the level of quantities of seed, labor and fertilizer are likely to increase the yield of local soybean varieties. Although, machinery, pesticide and harvester are positive and highly significant for the improved soybean varieties grower, there is no significant of these variables for the local soybean varieties growers. This indicates that most of the local soybean producers use traditional ways of soybean cultivation methods and they are more likely depending on labor.

The variance parameters are represented by the sigma squared $\left(\sigma^{2}\right)$ and gamma $(\gamma)$ in the stochastic frontier production function. The sigma-squared of improved soybean varieties is 1.241 and significant at the $5 \%$ level, and the sigma-squared of local soybean varieties is 0.1 and significant at the $1 \%$ level. It indicates the goodness of fit for the model and the appropriateness of the specified distributional assumption of the composite error terms in both varieties. The results are in line with the findings of Wadud and White (2000), and Dolisca and Jolly (2008).

The estimated values of variance parameter gamma $(\gamma)$ are 0.974 and 0.924 for improved and local soybean varieties, respectively, and both are significant at the $1 \%$ level. $\gamma$ is very close to 1 and significantly different from 0 , which means that high level of inefficiencies effects exists among the sampled farmers. Additionally, $97 \%$ and $92 \%$ of the variation in soybean yield is due to technical inefficiencies in the two varieties, respectively. Similar results were found in Mushunje, Belete, and Fraser (2003), and Asefa (2009). 
Table 6. Maximum likelihood estimates for parameters of the stochastic frontier and inefficiency analysis of Improved and Local Soybean Varieties

\begin{tabular}{|c|c|c|c|c|c|c|}
\hline \multirow{2}{*}{ Variable } & \multirow{2}{*}{ Parameters } & \multicolumn{2}{|c|}{ Improved Varieties } & \multicolumn{3}{|c|}{ Local Varieties } \\
\hline & & Coefficients & \multirow[t]{2}{*}{ t-ratios } & \multicolumn{2}{|c|}{ Coefficients } & \multirow[t]{2}{*}{ t-ratios } \\
\hline \multicolumn{5}{|c|}{ Stochastic frontier analysis } & & \\
\hline Constant & $\beta_{0}$ & $-2.759 * * *$ & -10.283 & -2.145 & $* * *$ & -5.303 \\
\hline Seed & $\beta_{1}$ & 0.049 & 0.882 & 0.193 & $* * *$ & 2.665 \\
\hline Labor & $\beta_{2}$ & $0.317 * * *$ & 5.657 & 0.147 & $* *$ & 2.376 \\
\hline Fertilizer & $\beta_{3}$ & $0.114 * * *$ & 3.667 & 0.209 & $* * *$ & 3.735 \\
\hline Machinery & $\beta_{4}$ & $0.286 * * *$ & 5.137 & -0.007 & & -0.098 \\
\hline Pesticide & $\beta_{5}$ & $0.071 * * *$ & 2.113 & -0.026 & & -0.569 \\
\hline Rhizobium & $\beta_{6}$ & -0.029 & -0.598 & -0.126 & & -1.153 \\
\hline Harvester & $\beta_{7}$ & $0.226 * * *$ & 4.412 & 0.073 & & 1.321 \\
\hline \multicolumn{7}{|c|}{ Inefficiency analysis } \\
\hline Constant & $\delta_{0}$ & $3.409 * *$ & 2.418 & -0.974 & & -1.147 \\
\hline Farm size & $\delta_{1}$ & $-0.653 * *$ & -2.207 & 0.195 & $* *$ & 2.542 \\
\hline Gender & $\delta_{2}$ & -0.081 & -0.513 & 0.158 & & 1.183 \\
\hline Age & $\delta_{3}$ & $-1.673 * *$ & -2.374 & 0.364 & $*$ & 1.834 \\
\hline Experience & $\delta_{4}$ & $-0.296 * *$ & -2.506 & 0.055 & & 0.828 \\
\hline Credit & $\delta_{5}$ & -0.022 & -0.164 & -0.258 & $* *$ & -2.355 \\
\hline Extension & $\delta_{6}$ & $-3.902 * *$ & -2.368 & -0.289 & $* *$ & -2.389 \\
\hline \multicolumn{7}{|c|}{ Variance parameters } \\
\hline Sigma-squared & $\sigma^{2}=\sigma_{u}^{2}+\sigma_{v}^{2}$ & $1.241 * *$ & 2.538 & 0.100 & $* * *$ & 3.028 \\
\hline Gamma & $\gamma=\sigma^{2}{ }_{u} / \sigma^{2}{ }_{v}$ & $0.974 * * *$ & 94.86 & 0.924 & $* * *$ & 15.02 \\
\hline Log likelihood & & 0.476 & & 3.794 & & \\
\hline LR test of the o & & 30.183 & & 47.044 & & \\
\hline Mean TE & & 0.850 & & 0.701 & & \\
\hline
\end{tabular}

Note. A negative sign of the parameters in the inefficiency function means that the associated variables have a positive effect on TE, while significant positive variables indicate the reverse.

$* * *, * *$, and $*$ indicate statistical significance at the $1 \%, 5 \%$, and $10 \%$ levels, respectively.

Source: Own calculation from field survey, 2016/17.

\subsection{Determinants of Technical Inefficiency}

Table 6 also shows the results of the estimation of socioeconomic variables in the inefficiency model. In the inefficiency model, the signs and coefficients are interpreted in the opposite way; the negative sign of the parameters in the inefficiency function suggests that the associated variables have a positive effect on technical efficiency, while positive significant variables indicate the reverse. For the improved soybean varieties' farmers, the results suggest that the coefficient estimate for farm size is negative and significant at the $5 \%$ level. This finding indicates that increasing the area of farm size lowers technical inefficiency in production, and there are greater efficiencies of improved soybean varieties' production on larger farm size. The result is in line with Dolisca and Jolly (2008), and Mignouna et al. (2010) who found that an increase in farm size leads to an increase in technical efficiency. The coefficient of age is negative and statistically significant at the $5 \%$ level. This means that older farmers tend to be more efficient in production. According to the descriptive statistics in Table 1, the younger farmers are more likely to adopt improved soybean varieties. The result suggests that, among these farmers, the technically more efficient farmers are older farmers because soybean farming experience increases with farmer's age and hence leading to an increase in efficiency. The findings are similar to Asefa (2009), and Otitoju and Arene (2013). The estimated coefficient of farm experience is negatively and statistically associated with technical inefficiency. This implies that farmers with more farming experience have greater technical efficiency, which would lead to the acquisition of better managerial skills over a period. The result is consistent with the finding of Ogunniyi (2008) and Yasin et al. (2014) who found that an increase in experience can reduce the inefficiency. The coefficient of extension access is found to be also negative and significant at the $5 \%$ level. This indicates that the more the extension contacts increase a farmers' knowledgeable on new farming practices and adoption of improved soybean varieties, the more would be the production efficiency. Similar results are also found in Khan and Saeed (2001) and Avea et al. (2016). For the local soybean varieties growers, farm size has a 
positive relationship with inefficiency. This implies that smallholder farmers are technically more efficient than farmers that have a large farm size, and this may be attributed to the fact that most of the local soybean varieties growers are smallholder farmers. If the farmers have a large farm size, they may face some difficulties to distribute critical production enhancing inputs to each plot. The finding is in line with the findings of $\mathrm{Chen}, \mathrm{Wu}$, and Zhao (2011). Age has a positive association with the technical inefficiency at a $10 \%$ significance level. This implies that older farmers are technically less efficient than the younger ones, and this may be attributed to the fact that older farmers may like to use the old and traditional cultural practices and not adopt new practices and modern inputs. The finding is in line with Amaza and Ogundari (2008). The negative association of coefficient of credit access and technical inefficiency at a 5\% significance level suggests that the higher the access to credit, the more efficient the farmer would become. Access to credit may enable farmers to purchase productive inputs on time. It may lead to higher production efficiencies. This result is also similar to the finding of Nchare (2007). The coefficient of extension access is also significant at a $5 \%$ level; this indicates that the farmers with more extension contacts have a higher production efficiency because extension contacts would help farmers to obtain knowledge on technical innovations, which, in turn, will improve their productivity. This result is consistent with Haji (2007).

\subsection{Distribution of Technical Efficiency}

The distribution of farmer's technical efficiency levels of improved and local soybean varieties is presented in Table 7. These results are obtained from the SFA; it can be realized that maximum technical efficiency of the improved soybean varieties' farmers is $95.06 \%$, while the minimum technical efficiency of improved soybean varieties' farmers is $32.61 \%$. The mean technical efficiency of improved varieties' farmers is $85.04 \%$, which implies that the farmers were able to obtain $85.04 \%$ of output from a given level of input, on an average. For the local soybean varieties' farmers, the efficiency level analysis reveals that the maximum technical efficiency of the local soybean varieties farmers' is $97.53 \%$, while the minimum technical efficiency of local soybean varieties' farmers is $21.63 \%$. The mean technical efficiency of local varieties' farmers is $70.13 \%$, which means that, on an average, the farmers are able to obtain $70.13 \%$ output from a given level of input. The obtained mean technical efficiency values of $85.04 \%$ and $70.13 \%$ in the present study are found in the studies of Battese, Coelli, and Colby (1989), Mushunje, Belete, and Fraser (2003), Idiong (2007), and Islam, Sumelius, and Bäckman (2012).

According to the results presented in Table 7 , improved soybean varieties have a relatively higher level of mean technical efficiency $(85.04 \%)$ than local varieties $(70.13 \%)$. Therefore, the adoption of improved soybean varieties would help farmers to improve their technical efficiency and enhance soybean yield. The results show that improved soybean varieties production is more efficient than local soybean varieties production. This indicates that local soybean varieties' producers have an enormous opportunity to increase the technical efficiency (29.87\%) for the local soybean varieties producers in trying to improve the production capacity in the Southern Shan State, Myanmar.

Table 7. Frequency distribution of technical efficiencies for improved and local soybean varieties farmers

\begin{tabular}{|c|c|c|c|c|}
\hline \multirow{2}{*}{ TE level (\%) } & \multicolumn{2}{|c|}{ Improved Soybean Varieties } & \multicolumn{2}{|c|}{ Local Soybean Varieties } \\
\hline & Household No. & Percent $(\%)$ & Household No. & Percent $(\%)$ \\
\hline$<50$ & 5 & 2.27 & 18 & 15.38 \\
\hline $50-59$ & 4 & 1.82 & 14 & 11.97 \\
\hline $60-69$ & 6 & 2.73 & 27 & 23.08 \\
\hline $70-79$ & 29 & 13.18 & 20 & 17.09 \\
\hline $80-89$ & 100 & 45.45 & 25 & 21.37 \\
\hline $90-100$ & 76 & 34.55 & 13 & 11.11 \\
\hline Total & 220 & 100.00 & 117 & 100.00 \\
\hline Mean & & 85.04 & & 70.13 \\
\hline Minimum & & 32.61 & & 21.63 \\
\hline Maximum & & 96.05 & & 97.53 \\
\hline
\end{tabular}

\subsection{The T-Test of Technical Efficiency of Improved and Local Soybean Varieties Production}

To compare and test the technical efficiency levels of improved and local soybean varieties, the STATA 12 computer programme was used in this study. According to the results presented in Table 8 , improved soybean varieties have a relatively higher level of mean technical efficiency $(85.04 \%)$ than local varieties $(70.14 \%)$; the 
results show a significant difference at $1 \%$ level between the two varieties. Therefore, the adoption of improved soybean varieties would help farmers to improve their technical efficiency and enhance soybean yield. The results show that improved soybean varieties production is more efficient than local soybean varieties production. This indicates that local soybean varieties' producers have an enormous opportunity to increase the technical efficiency $(29.87 \%$ ) for the local soybean varieties producers in trying to improve the production capacity in the Southern Shan State, Myanmar.

Table 8. Comparing the technical efficiency levels of improved and local soybean varieties production

\begin{tabular}{|c|c|c|c|c|c|}
\hline Variable & Mean & Std. Error & Std. Dev. & \multicolumn{2}{|c|}{ [95\% Conf. Interval] } \\
\hline TE of improved & 0.8504 & 0.0069 & 0.1018 & 0.8369 & 0.8639 \\
\hline TE of local & 0.7014 & 0.0153 & 0.1655 & 0.6711 & 0.7317 \\
\hline diff & 0.1490 & 0.0168 & 0.0637 & 0.1159 & 0.1821 \\
\hline
\end{tabular}

Note. $\mathrm{H}_{0}:$ mean (diff) $=0 ; \mathrm{H}_{\mathrm{a}}:$ mean $($ diff $)<0 ; \mathrm{H}_{\mathrm{a}}:$ mean $($ diff $) !=0 ; \mathrm{H}_{\mathrm{a}}:$ mean $($ diff $)>0 ; t=8.8865 * * *$.

$\operatorname{Pr}(\mathrm{T}<\mathrm{t})=1.0000 ; \operatorname{Pr}(|\mathrm{T}|>|\mathrm{t}|)=0.0000 ; \operatorname{Pr}(\mathrm{T}>\mathrm{t})=0.0000$.

\section{Conclusion and Policy Recommendation}

This study used logit model to assess and determine the factors affecting the adoption of improved soybean varieties. The analysis also showed that the adoption rate of improved soybean varieties is about $65 \%$ among the sampled farmers, which is presented in Table 4. The factors that affect the adoption of improved soybean varieties are education, market access, extension, and training access. The positive and significant impact of education on the adoption of improved soybean varieties indicates that the educated farmers are more likely to use improved soybean varieties. The government should emphasize the promotion of the farmers' formal education (e.g., the ability of farmers to read and write) and also to improve the farmer's knowledge through various training programs. The market access is positively and highly significant with the adoption; it means that the farmers who have market access can get better market information. Government and non-government organizations should create the market opportunities for improved soybean varieties' non-adopters to ensure that they adopt improved soybean varieties, while motivating the improved varieties' adopters to sustain adoption. Government and non-government organizations should also focus not only on improved varieties but also on improved market to get the more profit like searching market to get the higher price. The other factor that positively and significantly impacts on the adoption of improved soybean varieties is extension access. This implies that improved extension services are essential for disseminating the improved varieties and technologies to the farmers. The government should increase the number of extension workers who will introduce the improved varieties through field day, formal training, and demonstration fields. The training access has a positive and significant effect on the adoption of improved soybean varieties. This means that the farmers who get training on improved soybean varieties' production have a greater tendency to adopt improved soybean varieties. Therefore, the government should provide training on improved soybean cultivation; and the government should also increase knowledge and skill of the soybean farmers through technical programs on improved varieties and crop management practices.

This study also analyzes the differences in technical efficiencies between improved and local soybean varieties' production. The study also examines the determinants of technical inefficiency, by using a Cobb-Douglas stochastic frontier production function. The results show that improved and local soybean varieties production is depicted by performing various likelihood ratio tests on the parameters of the factors of both production and inefficiency. The findings indicate that the production factors, such as labor, fertilizer, and machinery, are positively and significantly influence the yield of improved soybean varieties through the use of pesticide and harvester while seed, labor, and fertilizer have positive and significant effects on the yield of local soybean varieties. This means that these are the important, significant inputs of soybean production in the study area. Moreover, although machinery, pesticide and harvester are positive and highly significant for the improved soybean varieties grower, there is no significant effect of these variables on the local soybean varieties growers. This indicates that most of the local soybean producers use traditional ways of soybean cultivation methods and they are more likely depending on labor. Therefore, government should provide knowledge and skills not only for the improved soybean producers but also for the local soybean producers to use pesticide effectively and to expand the use of farm machinery.

According to the efficiency analysis, mean technical efficiencies of improved and local soybean varieties are 
$85.04 \%$ and $70.13 \%$ respectively. This result indicates that improved soybean varieties production is more efficient than the local soybean varieties production. This result also means that there is an opportunity to increase the technical efficiency of local soybean varieties by about $29.87 \%$ through the improved use of available inputs, especially appropriate improved soybean varieties under a given technology. In addition, other factors such as farm size, age, farm experiences and extension access are significant relevant factors that influence the technical efficiency of improved soybean varieties, while credit and extension access are the significant factors affecting the technical efficiency of local soybean varieties. Therefore, the government should strengthen the efficient and effective extension services to increase the technical efficiency of soybean producing farmers. This will provide the farmers with the knowledge and skills essential for increasing technical efficiency. Moreover, the policy should focus on providing improved soybean varieties to the farmer's at a reasonable price and additionally, the improved varieties must be adaptable to the farmers' farming environment. These factors would contribute towards increasing the adoption of improved soybean varieties in Southern Shan State, Myanmar.

\section{Acknowledgements}

We are honored and greatly thankful to the ADB-JSP authorities for providing the financial support required completing the research. We also appreciate all the supports from the collaborating organizations (Ministry of Agriculture, Department of Planning, Department of Agriculture, Department of Agricultural Research, Myanmar). We would also like to express gratitude to all the farmers and the enumerators in all of the study areas.

\section{References}

Aigner, D., Lovell, C. A. K., \& Schmidt, P. (1977). Formulation and Estimation of Stochastic Frontier Production Function Models. Journal of Econometrics, 6(1), 21-37. https://doi.org/10.1016/0304-4076 (77)90052-5

Akudugu, M. A., Guo, E., \& Dadzie, S. K. (2012). Adoption of Modern Agricultural Production Technologies by Farm Households in Ghana: What Factors Influence Their Decisions? Journal of Biology, Agriculture and Healthcare, 2(3), 1-13. https://www.researchgate.net/profile/Samuel_Dadzie/publication/235751741_Adop tion_of_modern_agricultural_production_technologies_by_farm_households_in_Ghana_What_factors_infl uence_their_decisions/links/00463533b1249ebdf1000000.pdf

Amaza, P. S., \& Ogundari, K. (2008). An Investigation of Factors That Influence the Technical Efficiency of Soybean Production in the Guinea Savannas of Nigeria. Journal of Food, Agriculture \& Environment, 6(1), 92-96.

Asante, B. O., Wiredu, A. N., Martey, E., \& Sarpong, D. B. (2014). NERICA Adoption and Impacts on Technical Efficiency of Rice Producing Households in Ghana: Implications for Research and Development. American Journal of Experimental Agriculture, 4(3), 244-62. https://doi.org/10.9734/AJEA/2014/7250

Asefa, S. (2009). Analysis of Technical Efficiency of Crop Producing Smallholder Farmers in Tigray, Ethiopia. Munich Personal RePEc Archive (MPRA) Paper No. 40461. http://mpra.ub.uni-muenchen.de/40461

Avea, A. D., Jing, Z., Xu, T., Tomas, B., Tianxiang, L., Michael, R., \& William, F. (2016). Do NGOs and Development Agencies Contribute to Sustainability of Smallholder Soybean Farmers in Northern Ghana-A Stochastic Production Frontier Approach. Sustainability (Switzerland), 8(5), 465. https://doi.org/10.3390/ su8050465

Barry, S. (2016). The Socio-Economic and Institutional Determinants of Adoption of Improved Cowpea Varieties in Northern Burkina Faso. Asian Journal of Agricultural Extension, Economics \& Sociology, 14(2), 1-12. https://doi.org/10.9734/AJAEES/2016/30029

Battese, G. E., \& Coelli, T. J. (1995). A Model for Technical Inefficiency Effects in a Stochastic Frontier Production Function. Empirical Economics, 20, 325-32. https://doi.org/10.1007/BF01205442

Battese, G. E., Coelli, T. J., \& Colby, T. C. (1989). Estimation of Frontier Production Functions and the Efficiencies of Indian Farms Using Panel Data from Icrisat's Village Level Studies. Journal of Quantitative Economics, 5(2), 327-48.

Charnes, A., Cooper, W. W., \& Rhodes, E. (1978). Measuring the Efficiency of Decision Making Units. European Journal of Operational Research, 2(6), 429-44. https://doi.org/10.1016/0377-2217(78)90138-8

Chen, Y., Wu, B., \& Zhao, J. (2011). Excessive Fertiliser Input in Farmer-Level Soybean Production: Evidence from the Measurements of Technical Efficiency in Suihua City, China. Journal of Food, Agriculture and 
Environment, 9(3-4), 230-35.

Chianu, J., Bernard, V., John, M., Akin, A., \& Nteranya, S. (2006). Farmer Evaluation of Improved Soybean Varieties Being Screened in Five Locations in Kenya: Implications for Research and Development. African Journal of Agricultural Research, 1(5), 143-50.

Coelli, T. J. (1995). Recent Developments In Frontier Modelling and Efficiency Measurement. Australian Journal of Agricultural Economics, 39(3), 219-45. https://doi.org/10.1111/j.1467-8489.1995.tb00552.x

Coelli, T. J. (1996). A Guide to Frontier Version 4.1. A Computer Program for Stochastic Frontier, 7, 1-33. https://doi.org/10.1007/BF00158774

Coelli, T. J., Prasada Rao, D. S., O’Donnel, C. J., \& Batesse, G. E. (2005). An Introduction to Efficiency and Productivity Analysis. Springer, Boston, MA. https://doi.org/10.1007/978-1-4615-5493-6

Dey, M. M., Ferdinand, J. P., Gaspar, B. B., \& Prescilla, B. R. (2000). Technical Efficiency of Tilapia Growout Pond Operations in the Philippines. Aquaculture Economics \& Management, 4(1-2), 33-47. https://doi.org/10.1080/13657300009380259

Diro, S., \& Mulugeta, W. (2015). Determinants of Adoption of Soybean and Its Impact on the Livelihood of Smallholder Farmers in Jimma Zone. ZENITH International Journal of Multidisciplinary Research, 5(4), 119-38.

Dolisca, F., \& Jolly, C. M. (2008). Technical Efficiency of Traditional and Nontraditional Crop Production: A Case Study from Haiti. World Journal of Agricultural Sciences, 4(4), 416-26. Retrieved from http://www.idosi.org/wjas/wjas4(4)/2.pdf

Farrell, M. J. (1957). The Measurement of Productive Efficiency. Journal of the Royal Statistical Society, Series $A$ (General). https://doi.org/10.2307/2343100

Fatima, H., \& Khan, M. A. (2015). Research Article Influence of Wheat Varieties on Technical Efficiency and Production of Wheat Crop in Pakistan (In Selected Area of Punjab). Sarhad Journal of Agriculture, 31, 114-122. https://doi.org/10.17582/journal.sja/2015/31.2.114.122

Gebre, T. (2001). Maize Technoloyg Adoption in Ethiopia: Experiences from the Sasakawa-Global 2000 Agriculture Program. Enhancing the Contribution of Maize to Food Security in Ethiopia.

Goswami, K., Choudhury, H. K., \& Saikia, J. (2012). Forest Policy and Economics Factors in Fl Uencing Farmers' Adoption of Slash and Burn Agriculture in North East India. Forest Policy and Economics, 15, 146-51. https://doi.org/10.1016/j.forpol.2011.11.005

Greene, W. H. (2002). Econometric Analysis (5th ed.).

Gujarati, N. D. (2004). Basic Econometrics.

Haji, J. (2007). Production Efficiency of Smallholders' Vegetable-Dominated Mixed Farming System in Eastern Ethiopia: A Non-Parametric Approach. Journal of African Economies, 16(1), 1-27. https://doi.org/10.1093/ jae/ej1044

Idiong, I. C. (2007). Estimation of Farm Level Technical Efficiency in Smallscale Swamp Rice Production in Cross River State of Nigeria : A Stochastic Frontier Approach. World Journal of Agricultural Sciences, 3(5), 653-58. https://doi.org/10.5539/jas.v4n1p154

Idrisa, Y. L., Ogunbameru, B. O., \& Amaza, P. S. (2010). Influence of Farmers' Socio-Economic and Technology Characteristics on Soybean Seeds Technology Adoption in Southern Borno State, Nigeria. African Journal of Agricultural Research, 5(12), 1394-98. https://doi.org/10.4314/as.v9i3.65761

Islam, K. M. Z., Sumelius, J., \& Bäckman, S. (2012). Do Differences in Technical Efficiency Explain the Adoption Rate of HYV Rice? Evidence from Bangladesh. Agricultural Economics Review, 13, 93-110.

Kapalasa, E. G. (2014). Assessing Factors Influencing Farmers Adoption of Improved Soybean Varieties in Malawi. Journal of Agricultural Science, 4(6), 339-49.

Khai, H. V., Yabe, M., \& Yokogawa, H. (2008). Analysis of Productive Efficiency of Soybean Production in the Mekong River Delta of Viet Nam. Journal of Faculty of Agriculture, 53(1), 271-79.

Khan, H., \& Saeed, I. (2001). Measurement of Technical, Allocative and Economic Efficiency of Tomato Farms in Northern Pakistan. Journal of Agricultural Science and Technology, 2, 459-68.

Kodde, D. A., \& Palm, F. C. (1986). Wald Criteria for Jointly Testing Equality and Inequality Restrictions. 
Econometrica, 54(5), 1243-48. https://doi.org/10.2307/1912331

Kudi, T. M., Bolaji, M., Akinola, M. O., \& Nasa, I. D. H. (2011). Analysis of Adoption of Improved Maize Varieties among Farmers in Kwara State, Nigeria. International Journal of Peace and Development Studies, l(January), 8-12.

Latt, A. K., Hotta, K., \& Nanseki, T. (2011). Analysis of Technical Efficiency of Monsoon Rain-Fed Sesame Production in Myanmar: A Stochastic Frontier Approach. Journal of the Faculty of Agriculture, Kyushu University, 56(1), 177-84.

Lim, T. K. (2012). Edible Medicinal and Non Medicinal Plants (Vol. 9). Springer, New York, NY, USA. https://doi.org/10.1007/978-94-017-9511-1

Lopes, H. (2010). Adoption of Improved Maize and Common Bean Varities in Mozambique (Graduate Research Master's Degree Plan B Papers, Department of Agricultural, Food, and Resource Economics, Michigan State University, USA).

Meeusen, W., \& Broeck, C. (1977). Efficiency Estimation from Cobb-Douglas Production Functions with Composed Error. International Economic Review, 18(2), 435-44. https://doi.org/10.2307/2525757

Miah, M. A., Monayem, S. A., Rashid, M. A., \& Shiblee, S. A. M. (2015). Factors Affecting the Adoption of Improved Varieties of Mustard Cultivation in Some Selected Sites of Bangladesh. Bangladesh Journal of Agricultural Research, 40(3), 363. https://doi.org/10.3329/bjar.v40i3.25411

Mignouna, D. B., Mutabazi, K., Senkondo, E. M., \& Manyong, V. M. (2010). Adoption of a New Maize and Production Efficiency in Western Kenya. 2010 AAAE Third Conference/AEASA 48th Conference, September 19-23, 2010, African Association of Agricultural Economists, Cape Town, South Africa.

Mushunje, A., Belete, A., \& Fraser, G. (2003). Technical Efficiency of Resettlement Farmers of Zimbabwe. 41st Annual Conference of the Agricultural Economic Association of South Africa.

Mwatete, G. K. K., Kipkoech, A. K., Kipkorir, E. C., \& Sumukwo, J. (2015). Technical Efficiency Differentials between Rice Production Methods: The Case of Conventional and System of Rice Intensification in West Kano Irrigation Scheme, Kenya. Journal of Agricultural and Crop Research, 3(8), 130-40. http://sciencewebpublishing.net/jacr/archive/2015/December/pdf/Mwateteetal.pdf\%5Cnhttp://files/3049/M watete 2015.pdf

Myint, P. L., \& Napasintuwong, O. (2016). Economic Analysis of Paw San Rice Adoption in Myanmar. Asian Journal of Agricultural Research, 10, 175-184. https://doi.org/10.3923/ajar.2016.175.184

Nchare, A. (2007). Analysis of Factors Affecting the Technical Efficiency of Arabica Coffee Producers in Cameroon (AERC Research Paper 163). African Economic Research Consortium. Nairobi, Kenya.

Ogunniyi, L. T. (2008). Profit Efficiency among Cocoyam Producers in Osun State, Nigeria. International Journal of Agricultural Economics and Rural Development, 1(1), 38-46.

Ojiako, I. A., Manyong, V. M., \& Ikpi, A. E. (2007). Determinants of Rural Farmers' Improved Soybean Adoption Decisions in Northern Nigeria. Journal of Food, Agriculture and Environment, 5(2), 215-23.

Ologbon, O. A. C., Ikheloa, E. E., \& Akerele, E. O. (2012). Adoption of ' Ofada ' Rice Variety and Technical Efficiency of Rice-Based Production Systems in Ogun State, Nigeria Department of Agricultural Economics and Extension. World Journal of Agricultural Sciences, 8(6), 624-31. https://doi.org/10.5829/ idosi.wjas.2012.8.6.1638

Otitoju, M. A., \& Arene, C. J. (2013). Constraints and Determinants of Technical Efficiency in Medium-Scale Soybean Production in Benue State, Nigeria. Journal of Chemical Information and Modeling, 5(1), 160. https://doi.org/10.1017/CBO9781107415324.004

Oyekale, A. S., \& Idjesa, E. (2009). Adoption of Improved Maize Seeds and Production Efficiency in Rivers State, Nigeria. Academic Journal of Plant Sciences, 2(1), 44-50.

Salam, M. A., Siddique, M. A. B., \& Parvin, J. (2012). Assessment of Technical Efficiency of Inbred HYV and Hybrid Rice Cultivation at Farm Level. Bangladesh Journal of Agricultural Research, 37(2), 235-50. https://doi.org/10.3329/bjar.v37i2.11225

Taphe, B. G., Agbo, F. U., \& Ebe, F. E. (2015). Resource Productivity and Technical Efficiency of Small Scale Groundnut Farmers in Taraba State, Nigeria. Journal of Biology, Agriculture and Healthcare, 5(17), 25-36.

Tiongco, M., \& Hossain, M. (2015). Determinants of Adoption of Improved Cassava Varieties among Farming 
Households in Oyo, Benue, and Akwa Ibom States of Nigeria. HarverstPlus Working Paper 22.

Udensi, U. E., Gbassey, T., Ebere, U. F., Godwin, A., Chuma, E., Benjamen, C. O., ... Alfred, D. (2011). Adoption of Selected Improved Cassava Varieties among Smallholder Farmers in South-Eastern Nigeria. Journal of Food, Agriculture and Environment, 9(1), 329-35.

Wadud, A., \& White, B. (2000). Farm Household Efficiency in Bangladesh: A Comparison of Stochastic Frontier and DEA Methods. Applied Economics, 6846(June), 1665-73. https://doi.org/10.1080/000368400 421011

Wakili, A. M., \& Isa, A. H. (2015). Technical Efficiency of Small Scale Rice Production in Adamawa State, Nigeria (pp. 20-25). International Conference on Chemical, Food and Environment Engineering.

Win, N. K., \& Chumjai, P. (2009). Farmers Adoption of Improved Technological Knowledge on Soybean Production in Northern Shan State Area, Myanmar. Kasetsart Journal-Social Sciences, 30(2), 227-38.

Yasin, M. A., Muhammad, A., Sultan, A. A., \& Khuda, B. (2014). Profit Efficiency of Organic Vs Conventional Wheat Production in Rice-Wheat Zone of Punjab , Pakistan. Journal of Agricultural Research, 52(3), $439-52$.

Yusuf, O., \& Nwachukwu, W. (2015). Technical Efficiency of Institute for Agricultural Research (IAR) Developed Variety of Cowpea (Sampea 11) Production in Niger State, Nigeria. Journal of Animal Production, 27, 194-205.

\section{Copyrights}

Copyright for this article is retained by the author(s), with first publication rights granted to the journal.

This is an open-access article distributed under the terms and conditions of the Creative Commons Attribution license (http://creativecommons.org/licenses/by/4.0/). 